\title{
Application of response surface methodology for simultaneous removal of major cations from seawater using metal oxide nanostructures
}

\author{
Denga Ramutshatsha', J Catherine Ngila' ${ }^{1}$ Patrick G Ndungu' ${ }^{1}$ and Philiswa N Nomngongo ${ }^{1,2,3}$ \\ 'Department of Chemical Sciences, University of Johannesburg, Doornfontein Campus, PO Box 17011, Johannesburg, 2028, South Africa \\ ${ }^{2}$ DSI/Mintek Nanotechnology Innovation Centre, University of Johannesburg, Doornfontein, 2028, South Africa \\ ${ }^{3}$ DSI/NRF SARChI Chair: Nanotechnology for Water, University of Johannesburg, Doornfontein 2028, South Africa
}

The objectives of this study were to assess the suitability of metal oxide nanomaterials for removal of major cations $\mathrm{Na}^{+}, \mathrm{K}^{+}, \mathrm{Ca}^{2+}$ and $\mathrm{Mg}^{2+}$ from seawater. The as-synthesised nanomaterials were characterized using different techniques, such as XRD, TEM, and BET. The simultaneous removal of $\mathrm{Na}^{+}, \mathrm{K}^{+}, \mathrm{Ca}^{2+}$ and $\mathrm{Mg}^{2+}$ ion from aqueous solutions by $\mathrm{a}-\mathrm{Fe}_{2} \mathrm{O}_{3}$ and $\mathrm{SiO}_{2} / \mathrm{Nb}_{2} \mathrm{O}_{5} / \mathrm{Fe}_{2} \mathrm{O}_{3}$ nanostructures was studied using batch method. The influence of different experimental parameters (such as initial metal ion concentrations, mass of adsorbent, sample $\mathrm{pH}$ and contact time) that affect the simultaneous removal of metal ions was studied using response surface methodology (RSM) based on small central composite design (SCCD). Under optimised conditions, the highest percentage removal was $75 \%, 92 \%, 93 \%$ and $85 \%$ for $\mathrm{Na}^{+}, \mathrm{K}^{+}, \mathrm{Ca}^{2+}$ and $\mathrm{Mg}^{2+}$, respectively.

\section{INTRODUCTION}

Clean water is a prime requirement of human beings for their health and basic survival. Water pollution is increasing worldwide due to a large (and continually growing) population, industrial growth, commercial and agricultural activities (Schwarzenbach et al., 2006). Due to the increase in anthropogenic impacts, freshwater supplies suitable for potable use are becoming limited, especially at dry and arid locations (Daer et al., 2015). In addition, the scarcity of freshwater resources has resulted in mine-water and seawater being used as viable potable water resources (Glennon 2005; Barats et al., 2016). However, seawater has high salinity thus making it unfit for domestic purposes. Therefore, in order to cope with freshwater shortages, desalination has become one option for producing potable water from brackish water and seawater in many parts of the world (Ghaffour and Missimer 2013). Over the past decade, numerous commercial-scale desalination plants have been designed, built and operated. These include membrane distillation (Morillo et al., 2014), multi-effect desalination (Zhao et al., 2011), and membrane-based reverse osmosis plants (Nataraj et al., 2006). However, further research needs to be undertaken to optimize the performance of nano-scale membranes (Daer et al., 2015). It is important for researchers to develop commercially feasible technology for major and trace metal removal from seawater through improved overall system efficiency.

Among the above-mentioned techniques, adsorption is one of the most efficient methods for the removal of a wide range of metals, due to its high efficiency, easy operation and low cost (Ma et al., 2013). It is also known to be an efficient and economic method for the removal of pollutants from the environment (Fenglia and Wang, 2011). Removal efficiency for trace metals is mainly dependent on the surface properties of the adsorbent (Ma et al., 2013). For instance, an adsorbent with a large surface area can provide more adsorption sites. Conversely, the adsorbent surface is negatively charged at $\mathrm{pH}$ values higher than its point of zero charge (PZC), which is a benefit for adsorption/removal of trace metals (Ma et al., 2013). Recently, the use of nanometer-sized metal oxides as trace metal ion adsorbents has become an active area of research in the field of analytical science due to their special properties (Shishehbore et al., 2011; Hu et al., 2015; Zhang et al., 2015). The latter include small diameter, large specific surface area, corrosion resistance, non-toxicity and low cost, high chemical stability, unique electrical properties and the resultant superior mechanical properties (Chen et al., 2013).

Researchers have synthesised and characterized different nanometer-sized metal oxides such as alumina (Cui et al., 2011), titania (Huang and Hu 2011), iron oxide (Morillo et al., 2015), magnesium oxide (Purwajanti et al., 2015), and zirconia (Zheng et al., 2009), among others, nano-adsorbents and these solid materials have been applied for the removal of trace elements (such as $\mathrm{Cd}, \mathrm{Pb}, \mathrm{Hg}$, $\mathrm{As}, \mathrm{Zn}, \mathrm{Cu}$ and $\mathrm{Co}$, among others) in environmental samples.

In terms of saline solutions, Li et al. (2009) showed that ordered mesoporous carbon (OMC) can remove significant amounts of $\mathrm{NaCl}$ by adsorption, due to its high BET surface area of 1491 $\mathrm{m}^{2} \cdot \mathrm{g}^{-1}$ and ordered mesopores of $3.7 \mathrm{~nm}$. The recovery of high-purity magnesium solution from reverse osmosis brine by adsorption of $\mathrm{Mg}(\mathrm{OH})_{2}$ has been studied on the surface area of $\mathrm{Fe}_{3} \mathrm{O}_{4}$ micro-particles (Lehmann et al., 2014). This method has realised a significant improvement on the separation step for extracting and reuse of $\mathrm{Mg}$ (II) from seawater reverse osmosis (SWRO) brine. In

\section{CORRESPONDENCE}

Philiswa N Nomngongo

EMAIL

pnnomngongo@uj.ac.za

\section{DATES}

Received: 26 November 2018 Accepted: 30 March 2020

\section{KEYWORDS}

adsorption

brine

multivariable optimization

nanomaterials

seawater

\section{COPYRIGHT}

(c) The Author(s)

Published under a Creative

Commons Attribution 4.0

International Licence (CC BY 4.0) 
recent years, binary or ternary metal mixed oxides (such as ceriacoated silica-iron oxide; silica-coated iron oxide, silica-alumina and $\mathrm{SiO}_{2}-\mathrm{ZnO}-\mathrm{Al}_{2} \mathrm{O}_{3}$, among others) have been shown to exhibit superior properties as compared to single metal oxides (Diniz et al., 2014). The properties of nanometer-sized mixed oxide adsorbents include increased adsorbent reusability, stability and high adsorption capacity for metal ions over a wide $\mathrm{pH}$ range. In addition, these mixed oxide nanomaterials possess strong chemical activity as a result of the excess Lewis and Brønsted acid/base binding sites that permit high retention/adsorption of cationic and anionic metal species (Diniz et al., 2014; Kandula and Jeevanandam, 2015; Wutke et al., 2016).

Conventionally, optimization in adsorption methodologies has been performed using univariate techniques, i.e. monitoring one factor at time. However, the disadvantages of this method include the possibility of ambiguous results and interpretation because the interactive effects among the variables are not examined, and, secondly, that univariate optimization increases the number of experiments that need to be conducted. Therefore, this leads to an increase in analysis time as well as an increase in the consumption of reagents and materials (Bezerra et al., 2008). Statistical and design of experiments methods have been widely used at various stages of multivariate optimization strategy (Ferreira et al., 2007). Factorial design (either fractional of full) and RSM are the main statistical and mathematical tools which determine the significant factors and their optimum values (Bezerra et al., 2008, Benyounis and Olabi 2008). For instance, Namaghi et al., (2015) reported the use RSM based on Box-Behnken design for identification and optimization of key parameters in preparation of a thin-film composite membrane for water desalination. Mazaheri et al. (2015) applied RSM based on central composite design for simultaneous removal of methylene blue and $\mathrm{Pb}^{2+}$ ions using ruthenium nanoparticleloaded activated carbon. Other applications of multivariate techniques for optimization of batch adsorption methodologies are reported in the literature (e.g., Mourabet et al., 2015; Mondal and Roy, 2016; Rekadwad and Khobragade 2016).

The aim of this study was to investigate characteristics of hematite and $\mathrm{SiO}_{2} / \mathrm{Nb}_{2} \mathrm{O}_{5} / \mathrm{Fe}_{2} \mathrm{O}_{3}$ as an adsorbent for the removal of $\mathrm{Na}^{+}, \mathrm{K}^{+}, \mathrm{Ca}^{2+}$ and $\mathrm{Mg}^{2+}$ from brine solution in a batch system. Optimization of the following factors affecting the adsorption efficiency, such as solution $\mathrm{pH}$, contact time, initial concentration, and adsorbent mass, were investigated using RSM.

\section{EXPERIMENTAL}

\section{Materials and reagents}

Tetraethyl orthosilicate, (TEOS, $99.0 \%$ ), ethanol, hydrochloric acid, and $\mathrm{HNO}_{3}$ were acquired from Sigma-Aldrich. Standard solutions of $\mathrm{Na}^{+}, \mathrm{K}^{+}, \mathrm{Ca}^{2+}$ and $\mathrm{Mg}^{2+}$ were prepared from a $1000 \mathrm{mg} \cdot \mathrm{L}^{-1}$ stock solution by making appropriate dilutions using ultra-pure water. The $\mathrm{pH}$ of these solutions was adjusted by drop-wise additions of hydrochloric acid and ammonium obtained from associated chemical enterprises (ace).

\section{Instrumentation}

The quantification of the analyte $\left(\mathrm{Na}^{+}, \mathrm{K}^{+}, \mathrm{Ca}^{+2}\right.$ and $\left.\mathrm{Mg}^{2+}\right)$ was performed using an ICP-OES spectrometer (iCAP 6500 Duo, Thermo Scientific, UK) equipped with a charge injection device (CID) detector. The samples were introduced with a concentric nebulizer and a cyclonic spray chamber. The operating parameters of the instrument are reported in the supplementary data. The $\mathrm{pH}$ of the solution was adjusted and measured using OHAUS pH meter ST320. Dried samples from synthesis were calcined in a muffle furnace. The ultrasonic bath (Branson
Electronic 5800) was used to sonicate adsorption experiments. The crystallographic phases of all the samples were determined by X-ray diffraction (XRD) analysis using Panalytical X'Pert $\mathrm{X}$-ray Diffractometer, using $\mathrm{Cu} \mathrm{K} \alpha$ radiation, and $2 \theta$ scan from $4.00-80.00^{\circ}$ and a scan step time of $196.2 \mathrm{~s}$. Transmission electron microscopy (TEM) studies were performed at an acceleration voltage of $200 \mathrm{kV}$, using a Jeol JEM-2100F field emission electron microscopy instrument (JEOL Inc., Akishima, Japan). The TEM samples were prepared by dropping a small amount of synthesized sample into a Cu-grid coated with carbon film.

The surface area and pore size distribution of the samples were analysed using BET micrometrics ASAP 2020.

\section{Synthesis of porous $\mathrm{a}-\mathrm{Fe}_{2} \mathrm{O}_{3}$}

The synthesis of nanostructured $\alpha-\mathrm{Fe}_{2} \mathrm{O}_{3}$ was prepared by adapting the sol gel method reported by Shivakumara et al. (2014). In a typical synthesis, $12 \mathrm{~g}$ of $\mathrm{FeCl}_{3} \cdot 6 \mathrm{H}_{2} \mathrm{O}$ was dissolved in $100 \mathrm{~mL}$ of double-distilled water at room temperature. To the above solution, $20 \mathrm{~mL}$ of ethylene glycol was added slowly and continuously stirred for $1 \mathrm{~h}$. Once a red colloidal suspension formed, $1 \mathrm{M} \mathrm{NaOH}$ solution was added dropwise to increase the $\mathrm{pH}$ to 9 . The contents were stirred for a further $6 \mathrm{~h}$. The formed iron hydroxide was filtered and washed with distilled water several times followed by ethanol. The product was dried for 12 $\mathrm{h}$ at $60^{\circ} \mathrm{C}$. The dried sample was then heated for $3 \mathrm{~h}$ at $550^{\circ} \mathrm{C}$ in a muffle furnace.

\section{Preparation of $\mathrm{SiO}_{2} / \mathrm{Nb}_{2} \mathrm{O}_{5} / \mathrm{Fe}_{2} \mathrm{O}_{3}$ mixed oxide}

The synthesis procedure was adapted from the literature (Diniz et al., 2014). The material was prepared by mixing $133 \mathrm{~mL}$ tetraethyl orthosilicate (TEOS), $133 \mathrm{~mL}$ of ethanol and $11 \mathrm{~mL}$ of $3.5 \mathrm{~mol} /$ $\mathrm{HCl}$ together in a beaker. The solution was stirred at $35^{\circ} \mathrm{C}$ for $3 \mathrm{~h} .1 \mathrm{~g}$ iron oxide $\left(\mathrm{Fe}_{3} \mathrm{O}_{4}\right), 10.3 \mathrm{~g}$ of niobium chloride $\left(\mathrm{NbCl}_{5}\right)$, $10 \mathrm{~mL}$ of ethanol and $4 \mathrm{~mL}$ of $3.5 \mathrm{~mol} \mathrm{~L}^{-1} \mathrm{HCl}$ were added to the mixture. The solution was kept under stirring at $60^{\circ} \mathrm{C}$ for $20 \mathrm{~h}$. Solvent (ethanol) was then gently evaporated at $35^{\circ} \mathrm{C}$ for $2 \mathrm{~h}$ and the obtained material was milled to particle size $150-300 \mu \mathrm{m}$ using a ball mill. The material was then washed with $100 \mathrm{~mL}$ of $0.1 \mathrm{~mol} \mathrm{~L}^{-1} \mathrm{HNO}_{3}$, ethanol, deionized water and again with ethanol, after which it was further calcined at $550^{\circ} \mathrm{C}$ for $2 \mathrm{~h}$.

\section{Batch sorption studies}

The adsorption capacity of $\alpha-\mathrm{Fe}_{2} \mathrm{O}_{3}$ and $\mathrm{SiO}_{2} / \mathrm{Nb}_{2} \mathrm{O}_{5} / \mathrm{Fe}_{2} \mathrm{O}_{3}$ nanocomposite were assessed with a batch experiment using water samples of known initial concentrations. A batch experimental mode was adopted due to its simplicity. In the first set of experiments, $20 \mathrm{~mL}$ of $\mathrm{Na}, \mathrm{K}, \mathrm{Ca}$ and $\mathrm{Mg}$ solution contained in $100 \mathrm{~mL}$ plastic bottles were contacted with $0.1 \mathrm{~g}$ of $\alpha-\mathrm{Fe}_{2} \mathrm{O}_{3}$ and $\mathrm{SiO}_{2} / \mathrm{Nb}_{2} \mathrm{O}_{5} / \mathrm{Fe}_{2} \mathrm{O}_{3}$. The sealed bottles containing brine solution were placed in an ultrasonic bath for $25 \mathrm{~min}$ at $25^{\circ} \mathrm{C}$. After $25 \mathrm{~min}$ the samples were filtered by $0.22 \mu \mathrm{m}$ micro-filters. The filtrate was then analysed for residual brine concentration using ICP-OES. The $\mathrm{Na}^{+}, \mathrm{K}^{+}, \mathrm{Ca}^{2+}$ and $\mathrm{Mg}^{2+}$ percentage removal was calculated. All the experiments were carried out in triplicate.

\section{Application to real water samples}

Seawater samples were collected from the Indian Ocean, City of Durban (KwaZulu-Natal Province, South Africa). The seawater samples were collected in $1000 \mathrm{~mL}$ polyethylene bottles which were previously soaked in $10 \%$ nitric acid and rinsed twice with the ultrapure water and 3 times with the sample. This was done in order to reduce any possible elemental contamination. The samples were then stored at $4-8^{\circ} \mathrm{C}$ in the refrigerator. 


\section{RESULTS AND DISCUSSION}

\section{Characterization}

Figure 1a shows XRD patterns of $\alpha-\mathrm{Fe}_{2} \mathrm{O}_{3}$ samples calcined at $550^{\circ} \mathrm{C}$. The sharp peaks indicate that the sample is crystalline with characteristic rhombohedral structure of $a-\mathrm{Fe}_{2} \mathrm{O}_{3}$. Crystalline peaks for $\mathrm{Fe}_{2} \mathrm{O}_{3}$ appeared at 2 theta angles of $23.51^{\circ}$, 32. $81^{\circ}, 35.63^{\circ}, 40.70^{\circ}, 49.22^{\circ}, 53.54^{\circ}, 57.40^{\circ}, 62.23^{\circ}, 64.01^{\circ}$, $71.27^{\circ}, 75.46^{\circ}$, respectively. The most intense peak is ascribed to miller index 104 at 2 theta angle $32.81^{\circ}$. A plausible explanation for this is that by increasing the reaction temperature there is more energy within the solution. The XRD patterns obtained in this structure were similar to the XRD pattern obtained by Shivakumara et al. (2014). Figure $1 \mathrm{~b}$ shows the amorphous structure of $\mathrm{SiO}_{2} / \mathrm{Nb}_{2} \mathrm{O}_{5} / \mathrm{Fe}_{2} \mathrm{O}_{3}$ calcined at $550^{\circ} \mathrm{C}$. This may be due to the addition of amorphous $\mathrm{SiO}_{2}$. Amorphous $\mathrm{SiO}_{2}$ has shown some advantages in preparing highly active supported catalyst (Sun et al., 2013).

Figure 2 shows the typical TEM images of the resulting $\mathrm{Fe}_{2} \mathrm{O}_{3}$ nanoparticles and $\mathrm{SiO}_{2} / \mathrm{Nb}_{2} \mathrm{O}_{5} / \mathrm{Fe}_{2} \mathrm{O}_{3}$ adsorbent prepared through the sol gel method and calcined at $550^{\circ} \mathrm{C}$ temperature. TEM measurements at Fig. 2a. show that a few of the particles had a cubic shape, whereas most particles show a spherical morphology of $\mathrm{Fe}_{2} \mathrm{O}_{3}$. The TEM image for $\mathrm{SiO}_{2} / \mathrm{Nb}_{2} \mathrm{O}_{5} /$ $\mathrm{Fe}_{2} \mathrm{O}_{3}$ composite nanoparticles obtained showed that the $\mathrm{Nb}_{2} \mathrm{O}_{5} \mathrm{Fe}_{2} \mathrm{O}_{3}$ was coated by an amorphous layer of $\mathrm{SiO}_{2}$. Such shell structures for composite particles with $\mathrm{Nb}_{2} \mathrm{O}_{5}$ have been reported previously in the literature (Wang and Lee 2015; Xu et al., 2013).

In order to evaluate the surface area and porous nature of $\alpha-\mathrm{Fe}_{2} \mathrm{O}_{3}$ and $\mathrm{SiO}_{2} / \mathrm{Nb}_{2} \mathrm{O}_{5} / \mathrm{Fe}_{2} \mathrm{O}_{3}$ nanostructures, nitrogen adsorption-desorption isotherms were obtained. The specific surface area was calculated using the Brunauer-Emmett-Teller (BET) method. Shivakumaru et al. (2014) shows how the pore volume and surface area of $\alpha-\mathrm{Fe}_{2} \mathrm{O}_{3}$ samples decrease with an increase in preparation temperature. A relatively small surface area is observed with both materials $\left(6.7931 \mathrm{~m}^{2} \cdot \mathrm{g}^{-1}\right.$ for $\alpha-\mathrm{Fe}_{2} \mathrm{O}_{3}$ and $21.2029 \mathrm{~m}^{2} \cdot \mathrm{g}^{-1}$ for $\mathrm{SiO}_{2} / \mathrm{Nb}_{2} \mathrm{O}_{5} / \mathrm{Fe}_{2} \mathrm{O}_{3}$ ). The nanocomposite was comprised of a variety of metal oxides with different shapes and sizes; these different sizes and shapes ensure that there are more active sites (especially due to more atoms on the surface and edges of the composite) (Munonde et al., 2017).

\section{Selection of an adsorbent}

The selection of adsorbents for the removal of $\mathrm{Na}^{+}, \mathrm{K}^{+}, \mathrm{Ca}^{2+}$ and $\mathrm{Mg}^{2+}$ ions was conducted using a univariate approach. The
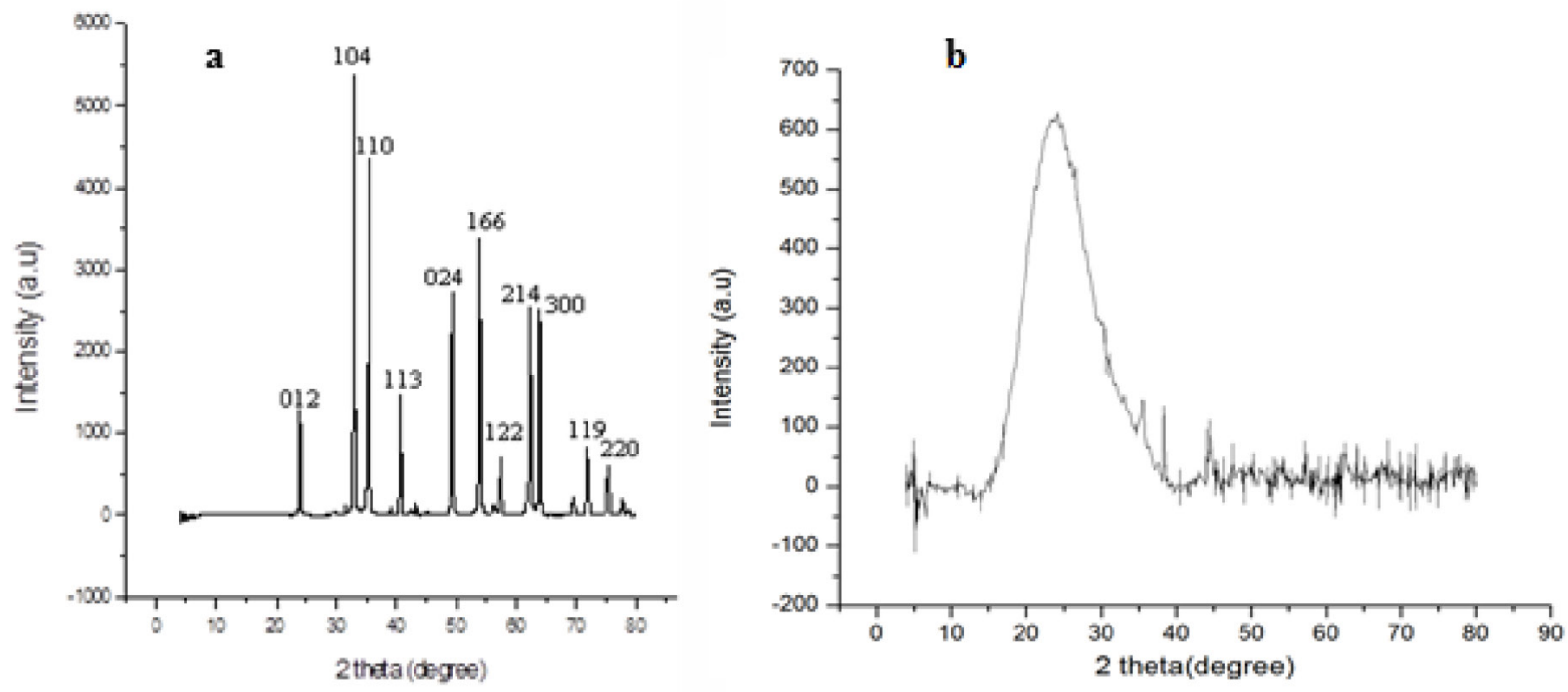

Figure 1. (a) XRD patterns of $\mathrm{a}-\mathrm{Fe}_{2} \mathrm{O}_{3}$ at $550^{\circ} \mathrm{C}$, (b) $\mathrm{XRD}$ patterns of $\mathrm{SiO}_{2} / \mathrm{Nb}_{2} \mathrm{O}_{5} / \mathrm{Fe}_{2} \mathrm{O}_{3}$ at $550^{\circ} \mathrm{C}$

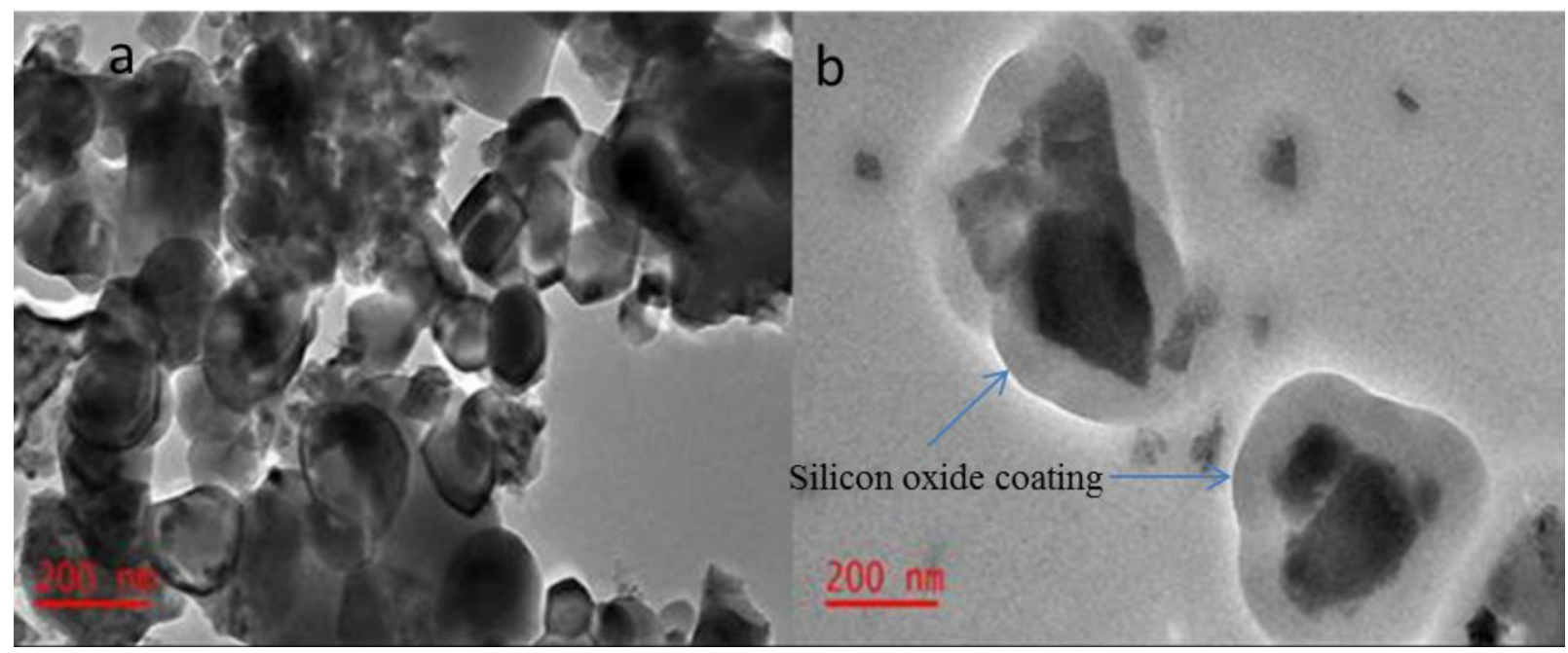

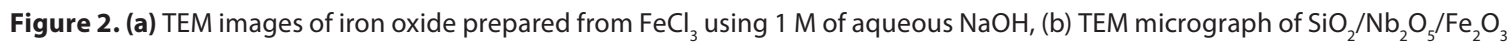


percentage removal efficiency, calculated using Eq. 1, was used to assess the performance of each adsorbent.

$$
\% R E=\frac{C_{o}-C_{f}}{C_{o}} \times 100
$$

where $C_{0}$ is the initial concentration of cations in a model seawater solution and $C_{\mathrm{f}}$ is the final concentration of metal ions in water after treatment.

From Fig. 3, it was observed that $\mathrm{SiO}_{2} / \mathrm{Nb}_{2} \mathrm{O}_{5} / \mathrm{Fe}_{2} \mathrm{O}_{3}$ was the best adsorbent for removal of all metal ions. Further experiments were conducted using $\mathrm{SiO}_{2} / \mathrm{Nb}_{2} \mathrm{O}_{5} / \mathrm{Fe}_{2} \mathrm{O}_{3}$.

\section{Point of zero charge on $\mathrm{SiO}_{2} / \mathrm{Nb}_{2} \mathrm{O}_{5} / \mathrm{Fe}_{2} \mathrm{O}_{3}$}

Zeta potential experiments were carried out to determine the $\mathrm{pH}$ at point of zero charge of $\mathrm{SiO}_{2} / \mathrm{Nb}_{2} \mathrm{O}_{5} / \mathrm{Fe}_{2} \mathrm{O}_{3}$. In addition, these experiments were performed in order to investigate the behaviour of the adsorbent at different $\mathrm{pH}$ values. The result for the zero-point charge $\mathrm{pH}_{\mathrm{pzc}}$ of the composite was found to be 4.5 . These results imply that $\mathrm{SiO}_{2} / \mathrm{Nb}_{2} \mathrm{O}_{5} / \mathrm{Fe}_{2} \mathrm{O}_{3}$ composite surface is negatively charged when the $\mathrm{pH}$ of the solution is higher than $\mathrm{pH}_{\mathrm{pzc}}$ and positively charged when $\mathrm{pH}_{\mathrm{ZPC}}$ is lower. This result

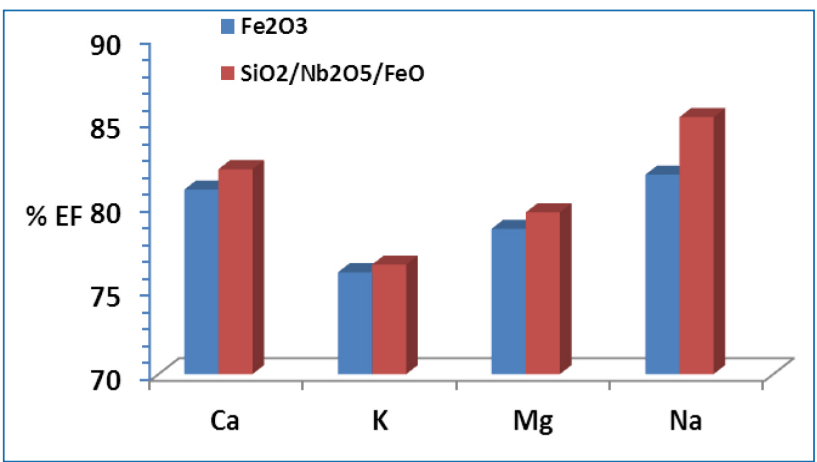

Figure 3. Comparing the removal efficiency of iron oxide and $\mathrm{SiO}_{2} /$ $\mathrm{Nb}_{2} \mathrm{O}_{5} / \mathrm{Fe}_{2} \mathrm{O}_{3}$ at natural $\mathrm{pH}$, initial concentrations of $850 \mathrm{mg} \cdot \mathrm{L}^{-1}$, contact time of $16 \mathrm{~min}$, temperature of $26^{\circ} \mathrm{C}$ and adsorbent mass of $0.1 \mathrm{~g}$ indicates the potential of the material to adsorb positively charged metals $\mathrm{Na}^{+}, \mathrm{Mg}^{2+}, \mathrm{Ca}^{2+}$ and $\mathrm{K}^{+}$at $\mathrm{pH}$ values of more than 4.5 , and to absorb the negatively charged ions such as $\mathrm{Cl}^{-}$and $\mathrm{SO}_{4}^{-2}$ at $\mathrm{pH}$ less than 4.5 .

\section{Optimization using response surface methodology}

The experimental parameters (sample $\mathrm{pH}$, contact time, initial concentration and adsorbent mass) affecting the simultaneous removal of metal ions were optimized using a multivariate approach. A response surface methodology based on central composite design was used to optimise the removal process. The CCD matrix and analytical results for each run $(n=3)$, performed as per the experimental design, are given in Table 1 . In order to assess the significance of the main effects and their interactions, the experimental results were statistically analysed by means of analysis of variance (ANOVA).

The ANOVA results presented in the form of a Pareto chart are shown in Fig. 4. It can be seen from Fig. 4 that the initial concentration (coded as (3) C (L)), $\mathrm{pH}$ (coded as $\mathrm{pH}(\mathrm{Q})$ ) and mass of adsorbent (coded as (2) MA(L)) were significant at the $95 \%$ confidence level and that the other factors and their interactions were not statistically significant. Therefore, it was clear that the simultaneous removal of major cations was dependent on the concentration of $\mathrm{Na}^{+}, \mathrm{K}^{+}, \mathrm{Ca}^{+}$and $\mathrm{Mg}^{2+}, \mathrm{pH}$, and mass of the adsorbent. In addition, it can be seen from Table 2 that as the initial metal ion concentration and mass of adsorbent increase the analytical response is affected. Therefore, the RSM model was used to obtain the optimum conditions.

Table 2. Confirmation experiments

\begin{tabular}{ccc}
\hline Analytes & $\begin{array}{c}\text { RSM predicted response } \\
\text { (\%) }\end{array}$ & $\begin{array}{c}\text { Confirmation } \\
\text { experiment response (\%) }\end{array}$ \\
\hline $\mathbf{N a}$ & $90.5 \pm 1.1$ & $93.6 \pm 1.2$ \\
$\mathbf{K}$ & $93.1 \pm 1.3$ & $94.3 \pm 0.9$ \\
$\mathbf{C a}$ & $91.2 \pm 1.6$ & $93.5 \pm 1.3$ \\
$\mathbf{M g}$ & $91.3 \pm 1.3$ & $93.2 \pm 1.4$ \\
\hline
\end{tabular}

Table 1. Central composite design matrix and analytical response

\begin{tabular}{|c|c|c|c|c|c|c|c|c|}
\hline \multirow{2}{*}{ Runs } & \multirow{2}{*}{ pH } & \multirow{2}{*}{ MA } & \multirow{2}{*}{ IC } & \multirow{2}{*}{ CT } & \multicolumn{4}{|c|}{ Removal efficiency (\%) } \\
\hline & & & & & $\mathrm{Na}$ & $K$ & $\mathrm{Ca}$ & $\mathbf{M g}$ \\
\hline 1 & 9 & 1 & 1000 & 5.0 & 81.83 & 79.85 & 81.01 & 79.04 \\
\hline 2 & 9 & 1 & 25 & 5.0 & 99.47 & 98.09 & 97.89 & 99.57 \\
\hline 3 & 9 & 0.1 & 1000 & 30.0 & 50.24 & 50.84 & 52.28 & 52.38 \\
\hline 4 & 2 & 1 & 25 & 30.0 & 61.98 & 60.82 & 66.22 & 64.59 \\
\hline 5 & 9 & 0.1 & 25 & 30.0 & 89.47 & 89.78 & 89.56 & 88.32 \\
\hline 6 & 2 & 0.1 & 1000 & 5.0 & 34.23 & 31.14 & 34.49 & 30.88 \\
\hline 7 & 2 & 1 & 1000 & 30.0 & 44.17 & 40.81 & 44.05 & 41.71 \\
\hline 8 & 2 & 0.1 & 25 & 5.0 & 61.98 & 63.75 & 680.96 & 62.69 \\
\hline 9 & 2 & 0.55 & 512 & 17.5 & 62.95 & 63.3 & 64.99 & 63.1 \\
\hline 10 & 9 & 0.55 & 512 & 17.5 & 86.03 & 82.87 & 85.27 & 81.74 \\
\hline 11 & 5.5 & 0.1 & 512 & 17.5 & 65.9 & 68.0 & 63.84 & 65.79 \\
\hline 12 & 5.5 & 1 & 512 & 17.5 & 96.51 & 98.83 & 98.46 & 98.49 \\
\hline 13 & 5.5 & 0.55 & 25 & 17.5 & 99.49 & 99.82 & 98.33 & 98.03 \\
\hline 14 & 5.5 & 0.55 & 1000 & 17.5 & 86.37 & 85.29 & 85.88 & 87.6 \\
\hline 15 & 5.5 & 0.55 & 512 & 5.0 & 86.16 & 80.73 & 84.52 & 80.38 \\
\hline 16 & 5.5 & 0.55 & 512 & 30.0 & 96.29 & 97.22 & 97.49 & 98.4 \\
\hline 17 & 5.5 & 0.55 & 512 & 17.5 & 98.16 & 98.24 & 98.69 & 98.68 \\
\hline 18 & 5.5 & 0.55 & 512 & 17.5 & 98.47 & 99.64 & 98.43 & 98.92 \\
\hline
\end{tabular}

$M A=$ adsorbent mass, $I C=$ initial concentration, $C T=$ contact time. Each run was performed in triplicate. 
To investigate the effect of two independent factors and their interactions on the removal efficiency for the major cations, the response surface plots were constructed based on the quadratic models using RSM. Figure 5 shows the 3D surface plots for the combined effect of sample $\mathrm{pH}$ and mass of adsorbent. It can be seen from Fig. 5 that removal efficiency was high when $\mathrm{pH}$ ranges from 6-7 with adsorbent mass of $0.5-1.0 \mathrm{~g}$. The combined effect of initial concentration and mass of the adsorbent is shown in Fig. $6 \mathrm{~b}$. It can be seen that the maximum removal efficiency was obtained when mass of the adsorbent was $1.0 \mathrm{~g}$ and the initial concentration of each analyte is between $800 \mathrm{mg} \mathrm{L}^{-1}$ and $1000 \mathrm{mg} \mathrm{L}^{-1}$.

The effect of initial concentration and sample $\mathrm{pH}$ on the analytical response (removal efficiency) is presented in Fig. 6 . The results obtained showed that the maximum removal efficiency was observed when the initial concentration and sample $\mathrm{pH}$ were at $1000 \mathrm{mg} \cdot \mathrm{L}^{-1}$ and 7, respectively. Figure $7 \mathrm{~b}$ represents the combined effect of contact time and sample $\mathrm{pH}$. It was

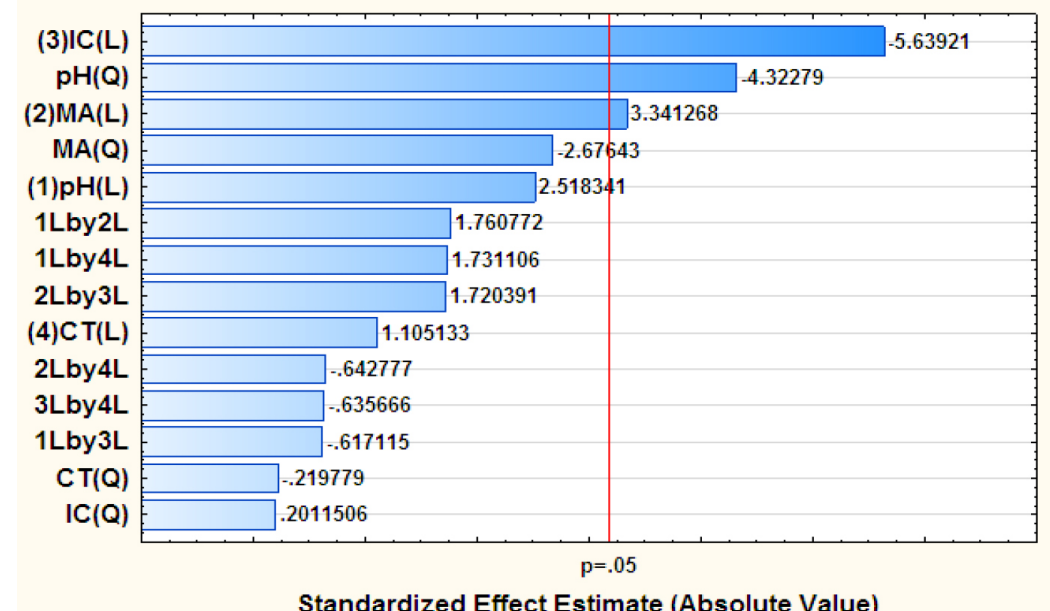

Figure 4. Pareto chart of standardized estimated effects caused by the investigated factors
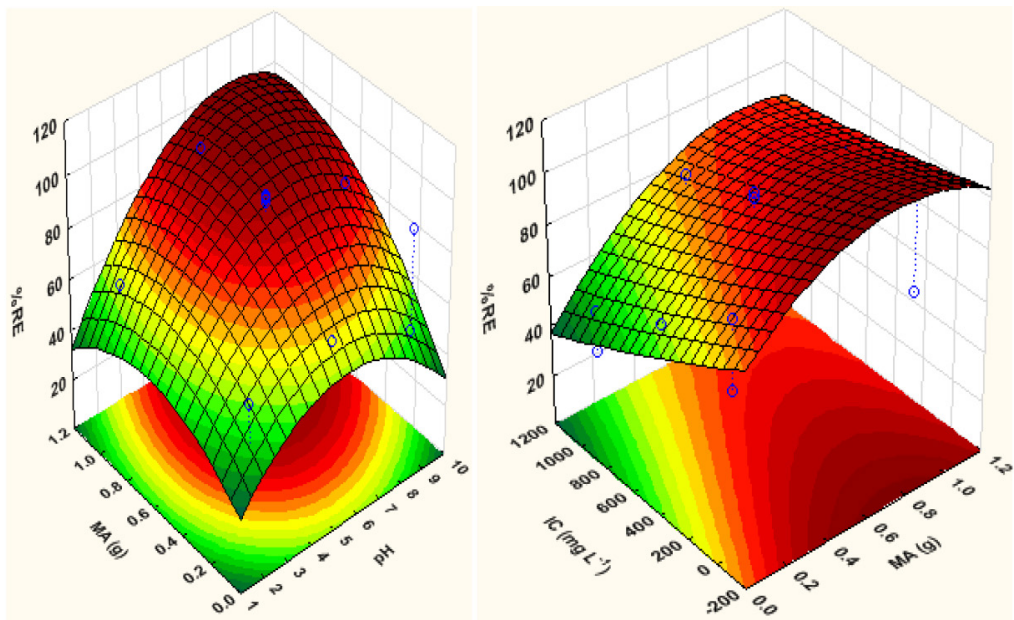

Figure 5. Response surface plot showing the combined effect of mass of adsorbent with sample pH and initial concentration on the \% removal efficiency: other factors were fixed at central point
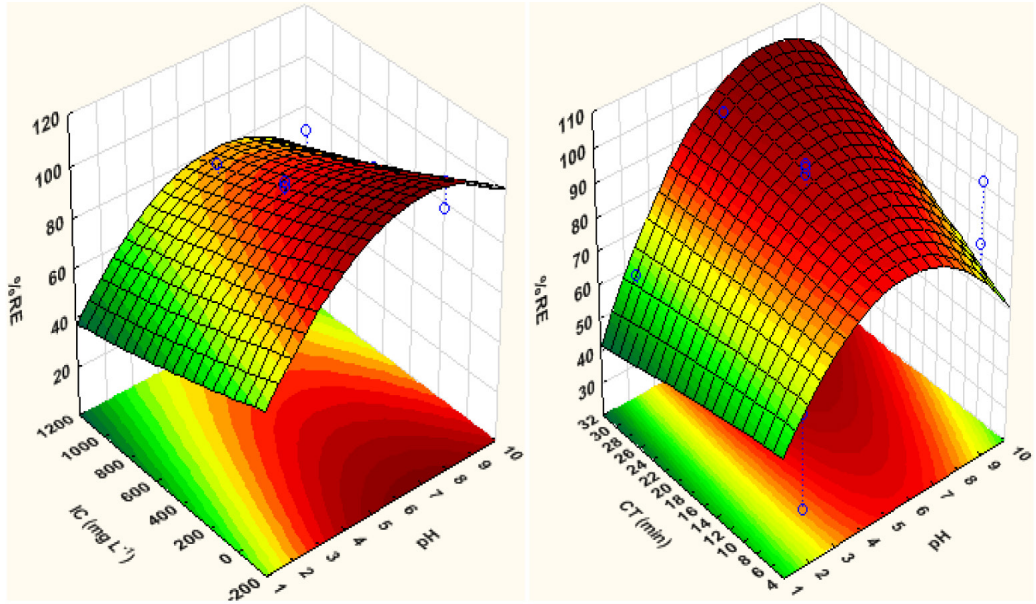

Figure 6. Response surface plot showing the combined effect of contact time with sample $\mathrm{pH}$ and initial concentration with sample $\mathrm{pH}$ on the $\%$ removal efficiency: other factors were fixed at central point 
observed that the quantitative removal of $\mathrm{Na}^{+}, \mathrm{K}^{+}, \mathrm{Ca}^{2+}$ and $\mathrm{Mg}^{2+}$ could be attained when the $\mathrm{pH}$ of the solution ranges from 6-8 and that the contact time did not show a significant effect on the analytical response. These observations were in agreement with the results shown in the Pareto chart and Table 2.

Figure 7 shows the combined effect of contact time, mass of adsorbent and initial concentration. The increase in MA value increases the removal efficiency. This observation was attributed to the availability of more adsorption sites. In addition, it can be seen from the response surface plot that percentage removal efficiency increases with increasing metal concentration up to about $1000 \mathrm{mg}$. $\mathrm{L}^{-1}$. As mentioned above, the effect of contact time did not have much influence on the analytical response.

The optimum values of the factors, i.e., sample $\mathrm{pH}$, extraction time, initial concentration and mass of the adsorbent, were obtained by checking the maxima formed by the $x$ - and $y$-coordinates (Xu et al., 2013) and confirmed by analysing the RSM quadratic equations (not included). Therefore, the optimum conditions for removal of $\mathrm{Na}, \mathrm{K}, \mathrm{Ca}$ and $\mathrm{Mg}$ were 7.5, $15,1500 \mathrm{mg} \mathrm{L}^{-1}$ and $1.0 \mathrm{~g}$ for sample $\mathrm{pH}$, extraction time, initial concentration and mass of adsorbent, respectively.

\section{Confirmation experiments}

The analytical data given by the RSM model under optimized conditions was validated by performing the confirmatory experiments conducted under the parameters suggested by the model ( $\mathrm{pH} 7.5$, adsorbent dose $0.1 \mathrm{~g}$, initial concentration 850 $\mathrm{mg} \cdot \mathrm{L}^{-1}$ and extraction time $16 \mathrm{~min}$ ) and the removal efficiencies are presented in Table 2. From the table, the results are in agreement with predicted values given by the RSM model.

\section{Adsorption equilibrium studies of $\mathrm{SiO}_{2} / \mathrm{Nb}_{2} \mathrm{O}_{5} / \mathrm{Fe}_{2} \mathrm{O}_{3}$}

Langmuir and Freundlich isotherm studies were carried out to understand the nature of the adsorption process that is taking place during removal of $\mathrm{Na}^{+}, \mathrm{K}^{+}, \mathrm{Ca}^{2+}$ and $\mathrm{Mg}^{2+}$ ions. The Langmuir isotherm describes a homogeneous monolayer chemical adsorption process, while the Freundlich isotherm describes the adsorption characteristics in a heterogeneous surface (Nomngongo et al., 2014; Hettiarachchi et al., 2016). The Langmuir and Freundlich linearized equations are represented by Eqs 2 and 3 (Nomngongo et al., 2014; Hettiarachchi et al., 2016; Langmuir 1918; Freundlich 1906).

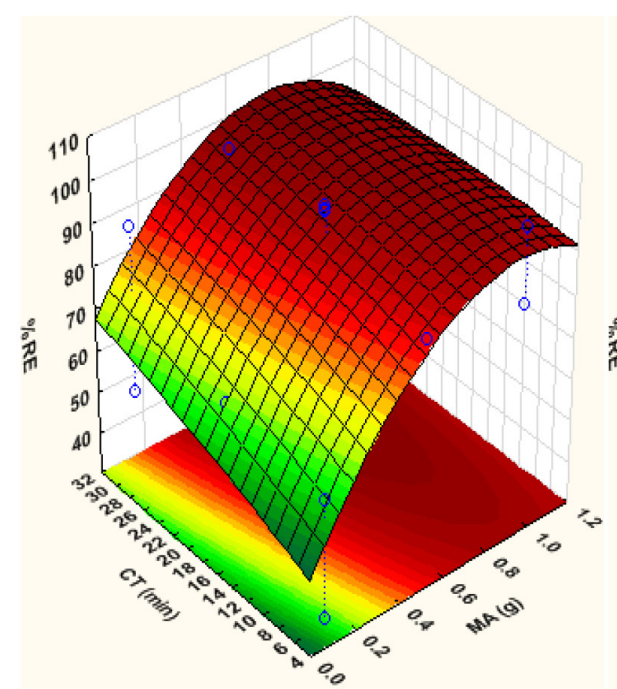

Langmuir linearized equation:

$$
\frac{C_{e}}{q_{e}}=\frac{1}{q_{\max }} C_{e}+\frac{1}{K_{L} q_{\max }}
$$

where: $q_{\mathrm{e}}\left(\mathrm{mg} \cdot \mathrm{g}^{-1}\right)$ and $C_{\mathrm{e}}\left(\mathrm{mg} \cdot \mathrm{L}^{-1}\right)$ are the amounts of adsorbed metal ion per unit gram of adsorbent and unadsorbed metal ion concentration in the solution at equilibrium, respectively. The constant $K_{\mathrm{L}}$ is the Langmuir equilibrium constant and $q_{\max }$ is the maximum monolayer adsorption capacity (Hettiarachchi et al., 2016).

Freundlich linearized equation:

$$
\ln q_{e}=\ln K_{f}+\frac{1}{n} \ln C_{e}
$$

where $K_{\mathrm{F}}$ is the Freundlich constant which relates to adsorption capacity and $n$ is the Freundlich exponent, which relates to adsorption intensity. The values of $K_{\mathrm{F}}$ and $n$ are calculated from a graph of $\log q_{\mathrm{e}}$ vs. $\log C_{\mathrm{e}}$.

The adsorption process of $\mathrm{Na}, \mathrm{K}, \mathrm{Ca}$ and $\mathrm{Mg}$ ions was carried out at different initial metal ion concentrations (500-5 000 $\mathrm{mg} \mathrm{L}^{-1}$ ) and the results are shown in Fig. 8. It can be seen from this figure that the removal of major cations through the adsorption

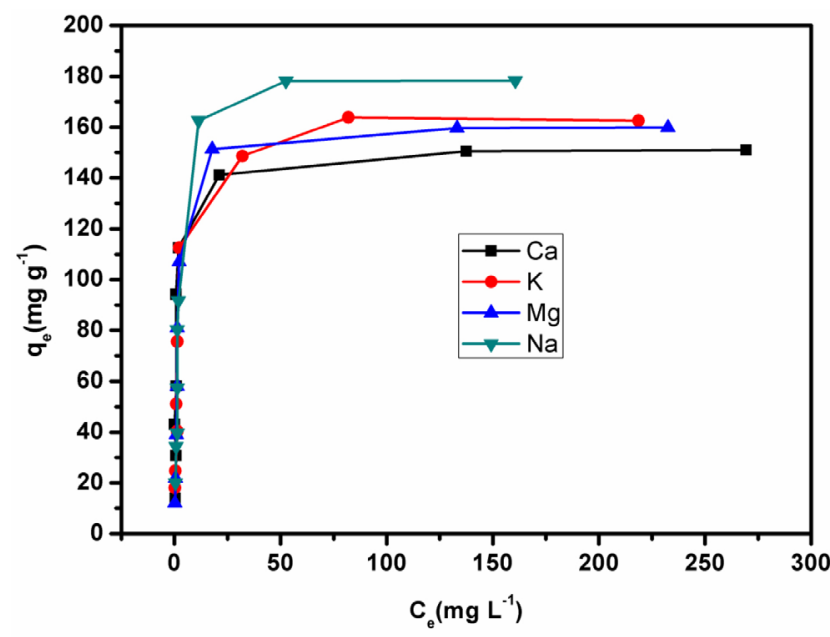

Figure 8. Equilibrium adsorption capacity for $\mathrm{Na}, \mathrm{K}, \mathrm{Ca}$ and $\mathrm{Mg}$ ions

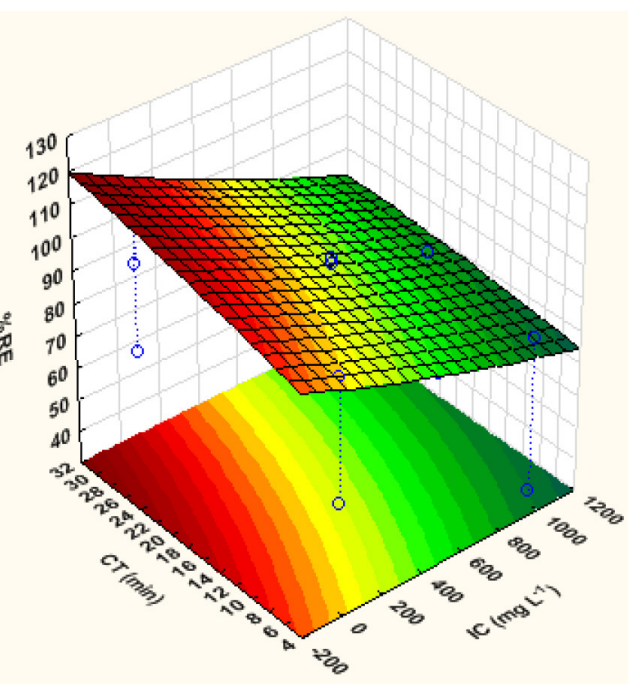

Figure 7. Response surface plot showing the combined effect of contact time with mass of adsorbent and initial concentration on the $\%$ removal efficiency: other factors were fixed at central point 
Table 3. Langmuir and Freundlich adsorption model parameters for adsorption of $\mathrm{Na}, \mathrm{K}, \mathrm{Ca}$ and $\mathrm{Mg}$ ions

\begin{tabular}{|c|c|c|c|c|}
\hline \multirow{2}{*}{$\begin{array}{l}\text { Cations } \\
\mathrm{Na}\end{array}$} & \multicolumn{2}{|c|}{ Langmuir parameters } & \multicolumn{2}{|c|}{ Freundlich parameters } \\
\hline & $q_{\max }\left(\mathrm{mg} \cdot \mathrm{g}^{-1}\right)$ & 181.8 & $K_{\mathrm{F}}$ & 1.4 \\
\hline & $K_{\mathrm{L}}\left(\mathrm{L} \cdot \mathrm{mg}^{-1}\right)$ & 0.37 & $N$ & 3 \\
\hline & $R^{2}$ & 0.9995 & $R^{2}$ & 0.7523 \\
\hline \multirow[t]{3}{*}{ K } & $q_{\max }\left(\mathrm{mg} \cdot \mathrm{g}^{-1}\right)$ & 163.9 & $K_{\mathrm{F}}$ & 1.3 \\
\hline & $K_{\mathrm{L}}\left(\mathrm{L} \cdot \mathrm{mg}^{-1}\right)$ & 0.45 & $N$ & 3 \\
\hline & $R^{2}$ & 0.9997 & $R^{2}$ & 0.7725 \\
\hline \multirow[t]{3}{*}{$\mathrm{Ca}$} & $q_{\max }\left(m g \cdot g^{-1}\right)$ & 151.5 & $K_{\mathrm{F}}$ & 1.4 \\
\hline & $K_{\mathrm{L}}\left(\mathrm{L} \cdot \mathrm{mg}^{-1}\right)$ & 0.67 & $N$ & 5 \\
\hline & $R^{2}$ & 0.9999 & $R^{2}$ & 0.4887 \\
\hline \multirow[t]{3}{*}{ Mg } & $q_{\max }\left(m g \cdot g^{-1}\right)$ & 161.3 & $K_{\mathrm{F}}$ & 1.3 \\
\hline & $K_{\mathrm{L}}\left(\mathrm{L} \cdot \mathrm{mg}^{-1}\right)$ & 0.47 & $N$ & 3 \\
\hline & $R^{2}$ & 0.9999 & $R^{2}$ & 0.7054 \\
\hline
\end{tabular}

process depended on the initial concentration of cations. For this reason, the adsorption-desorption equilibrium state is reached faster at low initial concentration, thus resulting in lower adsorption capacities (Hettiarachchi et al., 2016). This phenomenon is prevalent in cases where the adsorption process is that of a homogeneous monolayer. It should be noted that the adsorption process was performed using a multi-element standard that contains all four cations.

The results drawn from each isotherm parameter and the respective correlation coefficients are presented in Table 3. From the data, the adsorption process of major cations was better described by the Langmuir model than the Freundlich model.

\section{Removal of $\mathrm{Na}^{+}, \mathrm{K}^{+}, \mathrm{Ca}^{2+}$ and $\mathrm{Mg}^{2+}$ from seawater}

Natural seawater samples collected from Durban, South Africa, were used to evaluate the applicability of the optimized desalination method. According to ICP-OES results, the seawater samples contained $10786,370,403$ and $1283 \mathrm{mg} \cdot \mathrm{L}^{-1}$ of $\mathrm{Na}^{+}, \mathrm{K}^{+}, \mathrm{Ca}^{2+}$ and $\mathrm{Mg}^{2+}$, respectively; the $\mathrm{pH}$ and conductivity were found to be 8.1 and $4.83 \times 10^{5} \mu \mathrm{S}$. Results obtained are illustrated in Table 4 . It can be seen from this table that the removal efficiency was found to be $77 \%, 97 \%, 97 \%$ and $85 \%$ for

Table 4. Application of $\mathrm{SiO}_{2} / \mathrm{Nb}_{2} \mathrm{O}_{5} / \mathrm{Fe}_{2} \mathrm{O}_{3}$ composite for removal of major elements in real samples

\begin{tabular}{lcccc}
\hline \multirow{2}{*}{ Analytes } & \multicolumn{2}{c}{ Conc. $\left(\mathbf{m g} \cdot \mathbf{L}^{-1}\right)$} & \multirow{2}{*}{$\% R E$} & \multicolumn{2}{c}{ Conc. $\left(\mathbf{m g} \cdot \mathbf{L}^{-1}\right)$} & \multirow{2}{*}{ \%RE } \\
\cline { 2 - 3 } & Sample 1 & & Sample 2 & \\
\hline $\mathbf{N a}$ & $10393 \pm 29$ & $77.1 \pm 1.2$ & $10786 \pm 63$ & $76.3 \pm 1.3$ \\
$\mathbf{K}$ & $374 \pm 9$ & $96.5 \pm 1.4$ & $387 \pm 11$ & $97.3 \pm 1.1$ \\
$\mathbf{C a}$ & $403 \pm 7$ & $96.7 \pm 1.5$ & $394 \pm 9$ & $96.4 \pm 1.6$ \\
$\mathbf{M g}$ & $1273 \pm 13$ & $85.2 \pm 2.3$ & $1330 \pm 15$ & $84.5 \pm 1.8$ \\
\hline
\end{tabular}

$\mathrm{Na}^{+}, \mathrm{K}+, \mathrm{Ca}^{2+}$ and $\mathrm{Mg}^{2+}$, respectively. These results demonstrated that the $\mathrm{SiO}_{2} / \mathrm{Nb}_{2} \mathrm{O}_{5} / \mathrm{Fe}_{2} \mathrm{O}_{3}$ composite has the potential to be used for treating saline solutions such as seawater or brines.

The summary of some materials reported in the literature to treat saline water is shown in Table 5. Cao et al. (2009) showed that percentage of saline removal was greater than $90 \%$ when anion exchange membrane and cation exchange membrane were used to treat saline water.

\section{CONCLUSIONS}

The $\mathrm{SiO}_{2} / \mathrm{Nb}_{2} \mathrm{O}_{5} / \mathrm{Fe}_{2} \mathrm{O}_{3}$ composite was prepared as adsorbent for simultaneous removal of $\mathrm{Na}^{+}, \mathrm{K}^{+}, \mathrm{Ca}^{2+}$ and $\mathrm{Mg}^{2+}$ ion from seawater. The influential experimental parameters were optimized using central composite design. The quadratic equations from RSM were helpful in choosing the appropriate experimental parameters for effective adsorptive removal of $\mathrm{Na}^{+}, \mathrm{K}^{+}, \mathrm{Ca}^{2+}$ and $\mathrm{Mg}^{2+}$ in aqueous model solution. Validation experiments were carried out in order to confirm the results obtained by RSM model and the results were similar to those predicted using the model. The maximum percentage removal efficiency of metal ions from synthetic sample solutions and seawater samples ranged from $76-93 \%$ for $\mathrm{Na}^{+}, 94-97 \%$ for $\mathrm{K}^{+}, 75-93 \%$ for $\mathrm{Ca}^{2+}$ and 85-94\% for $\mathrm{Mg}^{2+}$. The equilibrium adsorption data were better represented by the Langmuir isotherm model with maximum adsorption capacities being 181.8, 163.9, 151.5, and $161.3 \mathrm{mg} \cdot \mathrm{g}^{-1}$, for $\mathrm{Na}^{+}, \mathrm{K}^{+}, \mathrm{Ca}^{2+}$ and $\mathrm{Mg}^{2+}$, respectively. X-ray diffraction and TEM image showed that the $\mathrm{Nb}_{2} \mathrm{O}_{5}$ and $\mathrm{Fe}_{2} \mathrm{O}_{3}$ were successfully coated by silica. The results further showed that the crystallite of $\mathrm{Nb}_{2} \mathrm{O}_{5} \mathrm{Fe}_{2} \mathrm{O}_{3}$ were dependent on the temperature. It can be concluded that $\mathrm{SiO}_{2} / \mathrm{Nb}_{2} \mathrm{O}_{5} / \mathrm{Fe}_{2} \mathrm{O}_{3}$ composite can be used as an adsorbent for removal of major cations $\mathrm{Na}^{+}, \mathrm{K}^{+}, \mathrm{Ca}^{2+}$ and $\mathrm{Mg}^{2+}$ from seawater. However, further investigation of its performance in a multi-bed adsorption system should be undertaken.

\section{ACKNOWLEDGEMENTS}

The authors would like to thank the DAAD/NRF joint in-country scholarships and Centre for Nanomaterials Science Research (University of Johannesburg, South Africa) for their financial assistance and the University of Johannesburg (UJ) for providing their laboratory facilities.

\section{REFERENCES}

BARATS A, ORANI AM, RENAC C, GOUDOUR JP, DURRIEU, G SAINT-MARTIN GH and HOYOS SG (2016) Behaviour and mobility of arsenic in a Mexican hydrosystem impacted by past mining activities. In: Arsenic Research and Global Sustainability: Proceedings of the Sixth International Congress on Arsenic in the Environment (As2016), 19-23 June 2016, Stockholm. CRC Press, Boca Raton. p. 191. https://doi.org/10.1201/b20466-93

BENYOUNIS KY and OLABI AG (2008) Optimization of different welding processes using statistical and numerical approaches - A reference guide. Adv. Eng. Softw. 39 483-496. https://doi. org/10.1016/j.advengsoft.2007.03.012

Table 5. Summary of salinity removal in desalination processes

\begin{tabular}{|c|c|c|c|}
\hline Material/adsorbent & Analyte & Removal efficiency (\%) & Reference \\
\hline $\mathrm{CO}_{2}$ hydrates & $\mathrm{Na}, \mathrm{Mg}, \mathrm{K}, \mathrm{B}$ & 78 & Park et al., 2011 \\
\hline $\begin{array}{l}\text { Magnetite multiwalled carbon } \\
\text { nanotube }\end{array}$ & $\mathrm{As}, \mathrm{Na}, \mathrm{Mg}, \mathrm{Ca}$ & $(58,70,67,73)$ & Mishra and Ramaprabhu 2010 \\
\hline Activated coconut coir (ACC) & $\mathrm{Na}, \mathrm{Mg}$ & $(72,82)$ & Hettiarachchi et al., 2016 \\
\hline Polyvinylidene (fluoride) & $\mathrm{Ca}, \mathrm{S}, \mathrm{O}, \mathrm{C}, \mathrm{Na}, \mathrm{Cl}, \mathrm{Mg}$ & $>99.9$ & Hou et al., 2013 \\
\hline Graphene sheet & $\mathrm{Na}, \mathrm{Mg}, \mathrm{Ca}, \mathrm{K}$ & $(68,71,60,56)$ & Mishra and Ramaprabhu, 2011 \\
\hline Gas hydrate $\left(\mathrm{CO}_{2}>\mathrm{CH}_{4}\right)$ & $\mathrm{Na}, \mathrm{K}, \mathrm{Mg}, \mathrm{Ca}, \mathrm{Cl}$ & 76 & Kang et al., 2014 \\
\hline
\end{tabular}


BEZERRA ML, SANTELLI RE, OLIVEIRA EP, VILLAR LS and ESCALEIRA LA (2008) Response surface methodology (RSM) as a tool for optimization in analytical chemistry. Talanta 76 965-977. https://doi.org/10.1016/j.talanta.2008.05.019

CAO X, HUANG X, LIANG P, XIAO K, ZHOU Y, ZHANG X and LOGAN BE (2009) A new method for water desalination using microbial desalination cells. Environ. Sci. Technol. 43 7148-7152. https://doi.org/10.1021/es901950j

CHEN S, ZHU S and LU D (2013) Titanium dioxide nanotubes as solid-phase extraction adsorbent for on-line preconcentration and determination of trace rare earth elements by inductively coupled plasma mass spectrometry. Microchem. J. 110 89-93. https://doi. org/10.1016/j.microc.2013.02.010

CUI C, HE M and HU B (2011) Membrane solid phase microextraction with alumina hollow fiber on line coupled with ICP OES for the determination of trace copper, manganese and nickel in environmental water samples. J. Hazardous Mater. 187 379-385. https://doi.org/10.1016/j.jhazmat.2011.01.038

DAER S, KHARRAZ J, GIWA A and HASAN SW (2015) Recen applications of nanomaterials in water desalination: a critical review and future opportunities. Desalination 367 37-48. https://oi org/10.1016/j.desal.2015.03.030

DINIZ KM, GORLA FA and RIBEIRO ES (2014) Preparation of $\mathrm{SiO}_{2} /$ $\mathrm{Nb}_{2} \mathrm{O}_{5} / \mathrm{ZnO}$ mixed oxide by sol-gel method and its application for adsorption studies and on-line preconcentration of cobalt ions from aqueous medium. Chem. Eng. J. 239 233-241. https://doi. org/10.1016/j.cej.2013.11.027

FENGLIAN F and WANG Q (2011) Removal of heavy metal ions from wastewaters: a review. J. Environ. Manage. 92 (3) 407-418. https:// doi.org/10.1016/j.jenvman.2010.11.011

FERREIRA SLC, BRUNS RE, DA SILVA EGP, DOS SANTOS WNL, QUINTELLA CM, DAVID JM and NETO BB (2007) Statistical designs and response surface techniques for the optimization of chromatographic systems. J. Chromatogr. A 1158 2-14. https://doi org/10.1016/j.chroma.2007.03.051

FREUNDLICH HMF (1906) Über die adsorption in lösungen. Z. Phys. Chem. 57 385-470. ttps://doi.org/10.1515/zpch-1907-5723

GHAFFOUR N, MISSIMER TM and AMY GL (2013) Technical review and evaluation of the economics of water desalination: current and future challenges for better water supply sustainability. Desalination 309 197-207. https://doi.org/10.1016/j.desal.2012.10.015

GLENNON R (2005) Scarcity, marketing, and privatization. Tex. L. Rev. 83 1873-1902.

HETTIARACHCHI E, PERERA R, CHANDANI PERERA ADL and KOTTEGODA N (2016) Activated coconut coir for removal of sodium and magnesium ions from saline water. Desalin. Water Treat. 57 22341-22352. https://doi.org/10.1080/19443994.2015.1129 649

HOU D, DAI G, WANG J, FAN H, LUAN Z and FU C (2013) Boron removal and desalination from seawater by PVDF flat-sheet membrane through direct contact membrane distillation. Desalination 326 115-124. https://doi.org/10.1016/j. desal.2013.07.023

HU B, HE M and CHEN B (2015) Nanometer-sized materials for solidphase extraction of trace elements. Anal. Bioanal. Chem. $4072685-$ 2710. https://doi.org/10.1007/s00216-014-8429-9

HUANG C and HU B (2011) Synthesis and characterization of titania hollow fiber and its application to the microextraction of trace metals. Analyst 136 1425-1432. https://doi.org/10.1039/c0an00660b

KANDULA S and JEEVANANDAM P (2015) Synthesis of Silica@ NiCo mixed metal oxide core-shell nanorattles and their potential use as effective adsorbents for waste water treatment.Eur. J. Inorg. Chem. 25 4260-4274. https://doi.org/10.1002/ejic.201500444

KANG KC, LINGA P, PARK KN, CHOI SJ and LEE JD (2014) Seawater desalination by gas hydrate process and removal characteristics of dissolved ions $\left(\mathrm{Na}^{+}, \mathrm{K}^{+}, \mathrm{Mg}^{2+}, \mathrm{Ca}^{2+}, \mathrm{B}^{3+}, \mathrm{Cl}^{-}, \mathrm{SO} 4{ }^{2-}\right)$. Desalination 353 84-90. https://doi.org/10.1016/j.desal.2014.09.007

LANGMUIR I (2018) The adsorption of gases on plane surfaces of glass, mica and platinum. J. Am. Chem. Soc. 30 1361-1403. https://doi. org/10.1021/ja02242a004

LEHMANN O, NIR O, KUFLIK M and LAHAV O (2014) Recovery of high-purity magnesium solutions from RO brines by adsorption of $\mathrm{Mg}(\mathrm{OH})_{2}$ (s) on $\mathrm{Fe}_{3} \mathrm{O}_{4}$ micro-particles and magnetic solids separation. Chem. Eng. J. 235 37-45. https://doi.org/10.1016/j. cej.2013.09.014

LI L, ZOU L, SONG H and MORRIS G (2009) Ordered mesoporous carbons synthesised by a modified sol-gel process for electro sorptive removal of sodium chloride. Carbon 47 775-781. https:// doi.org/10.1016/j.carbon.2008.11.012

MA Z, ZHU L, XING S, WU Y and GAO Y (2013) Facile synthesis of $\mathrm{Mn}$-Co oxide with a hierarchical porous structure for heavy metal removal. Mater. Lett. 108 261-263. https://doi.org/10.1016/j. matlet.2013.07.017

MAZAHERI H, GHAEDI M, HAJATI S, DASHTIAN K, PURKAIT MK (2015) Simultaneous removal of methylene blue and $\mathrm{Pb} 2+$ ions using ruthenium nanoparticle-loaded activated carbon: response surface methodology. RSC $A d v .5$ 83427-83435. https://doi. org/10.1039/C5RA06731F

MISHRA AK and RAMAPRABHU S (2010) Magnetite decorated multiwalled carbon nanotube based supercapacitor for arsenic removal and desalination of seawater. J. Phys. Chem. C $1142583-$ 2590. https://doi.org/10.1021/jp911631w

MISHRA AK and RAMAPRABHU S (2011) Functionalized graphene sheets for arsenic removal and desalination of sea water. Desalination 282 39-45. https://doi.org/10.1016/j.desal.2011.01.038

MOURABET M, EL RHILASSI A, EL BOUJAADY H, BENNANIZIATNI M, EL HAMRI R and TAITAI A (2015) Removal of fluoride from aqueous solution by adsorption on hydroxyapatite (HAp) using response surface methodology. J Saudi Chem. Soc. $19603-$ 615. https://doi.org/10.1016/j.jscs.2012.03.003

MONDAL NK and ROY S (2016) Optimization study of adsorption parameters for removal of phenol on gastropod shell dust using response surface methodology. Clean Technol. Environ. Polic. 18 429-447. https://doi.org/10.1007/s10098-015-1026-6

MORILLO J, USERO J, ROSADO D, EL BAKOURI H, RIAZA A and BERNAOLA FJ (2014) Comparative study of brine management technologies for desalination plants. Desalination 336 32-49. https://doi.org/10.1016/j.desal.2013.12.038

MORILLO D, UHEIDA A, PÉREZ G, MUHAMMED M and VALIENTE M (2015) Arsenate removal with 3-mercaptopropanoic acid-coated superparamagnetic iron oxide nanoparticles. J. Colloid Interface Sci. 438 227-234. https://doi.org/10.1016/j.jcis.2014.10.005

MUNONDE TS, MAXAKATO NW and NOMNGONGO PN (2017) Preconcentration and speciation of chromium species using ICPOES after ultrasound-assisted magnetic solid phase extraction with an amino-modified magnetic nanocomposite prepared from $\mathrm{Fe}_{3} \mathrm{O}_{4}$, $\mathrm{MnO}_{2}$ and $\mathrm{Al}_{2} \mathrm{O}_{3}$. Microchim. Acta 184 (4) 1223-1232. https://doi. org/10.1007/s00604-017-2126-2

NAMAGHI HA, ASL AH and CHENAR MP (2015) Identification and optimization of key parameters in preparation of thin film composite membrane for water desalination using multi-step statistical method. J. Ind. Eng. Chem. 31 61-73. https://doi.org/10.1016/j. jiec.2015.06.008

NATARAJ SK, HOSAMANI KM and AMINABHAVI TM (2006) Distillery wastewater treatment by the membrane-based nanofiltration and reverse osmosis processes. Water Res. 402349 2356. https://doi.org/10.1016/j.watres.2006.04.022

NOMNGONGO PN, NGILA JC, MSAGATI TA and MOODLEY B (2014) Kinetics and equilibrium studies for the removal of cobalt, manganese, and silver in ethanol using Dowex 50W-x 8 cation exchange resin. Sep. Sci. Technol. 49 1848-1859. https://doi.org/10. 1080/01496395.2014.907317

PARK KN, HONG SY, LEE JW, KANG KC, LEE YC, HA MG and LEE JD (2011) A new apparatus for seawater desalination by gas hydrate process and removal characteristics of dissolved minerals $\left(\mathrm{Na}^{+}, \mathrm{Mg}^{2+}, \mathrm{Ca}^{2+}, \mathrm{K}^{+}, \mathrm{B}^{3+}\right)$. Desalination 274 (1) 91-96. https://doi. org/10.1016/j.desal.2011.01.084

PURWAJANTI S, ZHOU L, AHMAD NOR Y, ZHANG J, ZHANG $\mathrm{H}$, HUANG X and YU C (2015) Syn thesis of magnesium oxide hierarchical microspheres: a dual-functional material for water remediation. ACS Appl. Mater. Interf. 7 21278-21286. https://doi. org/10.1021/acsami.5b05553

REKADWAD BN and KHOBRAGADE CN (2016) Digital data for Quick Response (QR) codes of thermophiles to identify and compare the bacterial species isolated from Unkeshwar hot springs (India). Data in Brief 6 53-67. https://doi.org/10.1016/j.dib.2015.11.035 
SCHWARZENBACH RP, ESCHER BI, FENNER K, HOFSTETTER TB, JOHNSON CA, VON GUNTEN, U and WEHRLI B (2006) The challenge of micro pollutants in aquatic systems. Science 3131072 1077. https://doi.org/10.1126/science.1127291

SHISHEHBORE M, AFKHAMI A and BAGHERI H (2011) Salicylic acid functionalized silica-coated magnetite nanoparticles for solid phase extraction and preconcentration of some heavy metal ions from various real samples. Chem. Cent. J. 5 1-10. https://doi. org/10.1186/1752-153X-5-41

SHIVAKUMARA S, PENKI TR and MUNICHANDRAIAH N (2014) Preparation and electrochemical performance of porous hematite $\left(\alpha-\mathrm{Fe}_{2} \mathrm{O}_{3}\right)$ nanostructures as supercapacitor electrode material. J. Solid State Electrochem. 18 1057-1066. https://doi.org/10.1007/ s10008-013-2355-1

SUN Z, BAI C, ZHENG S, YANG X and FROST RLA (2013) Comparative study of different porous amorphous silica minerals supported $\mathrm{TiO}$ catalysts. Appl. Catal. A: Gen. 458 103-110. https://doi.org/10.1016/j. apcata.2013.03.035

WUTKE NB, DINIZ KM, CORAZZA MZ, OLIVEIRA FMD, RIBEIRO ES, DA FONSECA BT and TEIXEIRA TARLEY CR (2016) Preconcentration of nickel (II) by a mini-flow system with a novel ternary oxide solid phase and flame atomic absorption spectrometry. Anal. Lett. 49 723-736. https://doi.org/10.1080/0003 2719.2015.1041025
WANG X and LEE PS (2015) Titanium doped niobium oxide for stable pseudocapacitive lithium ion storage and its application in $3 \mathrm{~V}$ nonaqueous supercapacitors. J. Mater. Chem. A 3 21706-21712. https:// doi.org/10.1039/C5TA04776E

XU M, YIN P, LIU X, DONG X, YANG Y, WANG Z and QU R (2013) Optimization of biosorption parameters of $\mathrm{Hg}$ (II) from aqueous solutions by the buckwheat hulls using respond surface methodology. Desalin. Water Treat. 51 4546-4555. https://doi.org/ 10.1080/19443994.2013.770591

ZHAO D, XUE J, LI S, SUN H and ZHANG QD (2011) Theoretical analyses of thermal and economical aspects of multi-effect distillation desalination dealing with high-salinity wastewater. Desalination 273 292-298. https://doi.org/10.1016/j.desal.2011.01.048

ZHANG Y, ZHONG C, ZHANG Q, CHEN B, HE M and HU B (2015) Graphene oxide- $\mathrm{TiO}_{2}$ composite as a novel adsorbent for the preconcentration of heavy metals and rare earth elements in environmental samples followed by on-line inductively coupled plasma optical emission spectrometry detection. RSC Advances 5 5996-6005. https://doi.org/10.1039/C4RA13333A

ZHENG FY, LI SX, LIN LX and CHENG, LQ (2009) Simple and rapid spectrophotometric determination of trace titanium (IV) enriched by nanometer size zirconium dioxide in natural water. J. Hazardous Mater. 172 618-622. https://doi.org/10.1016/j.jhazmat.2009.07.042 